\title{
Establishing a 501(c)(3) Nonprofit Organization: An Overview ${ }^{1}$
}

\author{
Jacqueline Phillips, Jorge Ruiz-Menjivar, Jennifer A. Jones, and Julianne Shoup ${ }^{2}$
}

A 501(c)(3) organization is the most common type of nonprofit organization in the United States. Per the National Center for Charitable Statistics, there are over 1,400,700 registered 501(c)(3) organizations in the United States. The benefits of having 501(c)(3) status include exemption from federal income tax and certain employment taxes. 501(c)(3) organizations may also be eligible to receive tax-deductible charitable contributions. Section 501(c)(3) of the Internal Revenue Code presents general guidelines for organizations that seek tax-exempt status. In this publication, we provide an overview of the process to establish a 501(c)(3) nonprofit organization. We pay special attention to the eligibility criteria and the filing requirements involved in the formation process.

\section{Eligibility Guidelines and Other Requirements}

- For an organization to be exempt from federal income tax, it must be organized and operated exclusively for one or more exempt purposes. To be tax-exempt, an organization must state one or more exempt purposes in its documents. Section 501(c)(3) of the IRC lists the following exempt purposes: charitable, educational, religious, scientific, literary, fostering national or international sports competition, preventing cruelty to children or animals, and testing for public safety.
- A 501(c)(3) organization must be organized as a corporation, trust, or association. The organizing documents must not expressly permit activities that do not further its exempt purposes. These documents must also permanently dedicate its assets to exempt purposes.

- A 501(c)(3) organization must refrain from participating in the political campaigns of candidates, limit its lobbying activities to an insubstantial part of its total activities, and refuse to operate for the benefit of private interests such as those of its shareholders (National Council of Nonprofits, 2019).

- The organization must also not have purposes or activities that are illegal or violate fundamental public policy. For example: an organization formed to promote world peace that planned and sponsored protest demonstrations at which members were urged to commit acts of civil disobedience would not qualify for 501(c)(3) status or exemption.

- Federal tax law also imposes responsibilities on organizations receiving 501(c)(3) status. 501(c)(3) organizations are required to keep books and records detailing all activities and to file an annual information return (IRS Form 990).

- Nonprofit organizations are permitted to engage in market-based activities. These activities may or may not be taxed, depending on the extent to which they are related to the mission, are regularly carried out, and are

1. This document is FCS3350, one of a series of the Department of Family, Youth and Community Sciences, UF/IFAS Extension. Original publication date April 2019. Visit the EDIS website at https://edis.ifas.ufl.edu for the currently supported version of this publication.

2. Jacqueline Phillips, undergraduate student; Jorge Ruiz-Menjivar, assistant professor; Jennifer A. Jones, assistant professor, Department of Family, Youth and Community Sciences; and Julianne Shoup, Extension agent I, UF/IFAS Extension Jefferson County; UF/IFAS Extension, Gainesville, FL 32611.

The Institute of Food and Agricultural Sciences (IFAS) is an Equal Opportunity Institution authorized to provide research, educational information and other services only to individuals and institutions that function with non-discrimination with respect to race, creed, color, religion, age, disability, sex, sexual orientation, marital status, national origin, political opinions or affiliations. For more information on obtaining other UF/IFAS Extension publications, contact your county's UF/IFAS Extension office. 
conducted by volunteers or paid staff (IRS, 2018). If an exempt organization has $\$ 1,000$ or more of gross income from an unrelated trade or business during the year, it must file a 990 - $\mathrm{T}$ form.

- All 501(c)(3) organizations must make their applications, core governing documents, and the annual IRS Form 990 returns available to the public for inspection. The IRS Form 990s are generally posted on websites such as Guidestar.org.

\section{Filing Requirements}

- Organizations that want to apply for 501(c)(3) status at the federal level must file the following forms: SS-4, Form 1023 or 1023-EZ.

- SS-4: The SS-4 form is an application for an employer identification number. If the organization does not already have an EIN, it will need to apply for one. This form can be submitted online.

- Form 1023: This form is the application for recognition of exemption as a 501(c)(3) and must be submitted via mail. Form 1023-EZ is a streamlined form for smaller organizations, and it must be submitted online. There is a worksheet for determining eligibility for the 1023-EZ.

- Form 2848: This is a power of attorney form. If a third party is going to represent the organization, this form must be completed.

- Form 8821: This is a tax information authorization form. If a third party needs access to your tax information but will not represent the organization, this form needs to be completed.

- Organizations must also develop and submit copies of their Articles of Incorporation and their bylaws. If an organization meets the requirements for exemption, the IRS will issue a determination letter recognizing the organization's exempt status. This is an important document that should be kept in the organization's permanent records.

- Articles of Incorporation and bylaws are core governing documents that codify the organization's mission, geographic focus, initial board composition, membership composition (if any), and the way governing will function (e.g., board membership, voting). Templates for these documents are readily available online; however, it is strongly recommended that founding members use the process of developing these documents as an opportunity to engage in a thoughtful deliberation of the identity of the organization.
- New organizations that have been organized for fewer than three tax years will also need to submit financial documents, including current year financials and proposed budgets for the next two years.

- Organizations must also apply for tax exemption at the state level. The process varies by state, and state-specific guidelines and processes are usually available through the State Attorney General's office. In some cases, this office is housed in a separate department. For example, in Florida, charities are managed through the Florida Department of Agriculture and Consumer Services.

- If you are engaged in fundraising, many states require you to also register and report fundraising activities annually. Check with your state-level authority for details. If you are asking for donations in states beyond the state in which you are headquartered, additional registration may be necessary (National Council of Nonprofits, 2015).

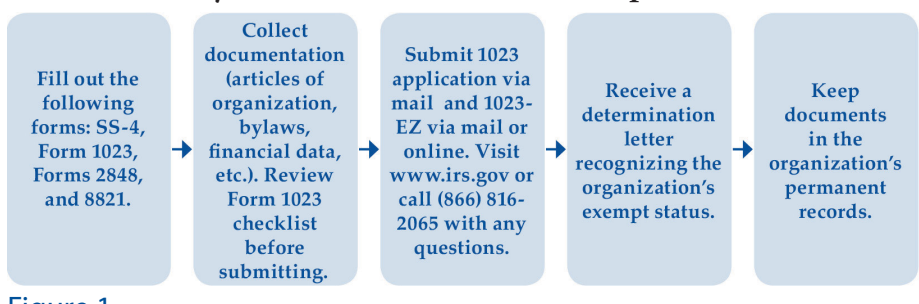

Figure 1.

Credits: UF/IFAS

\section{Helpful Links}

- EIN Application: https://www.irs.gov/businesses/small-businesses-self-employed/ apply-for-an-employer-identification-number-ein-online

- EIN Form: https://www.irs.gov/charities-non-profits/ employer-identification-number

- Form 1023 and 1023-EZ Directions: https://www.irs.gov/ forms-pubs/about-form-1023ez

- Step-by-Step Analysis of Eligibility for Application: https://www.irs.gov/charities-non-profits/ application-process

- IRS Pub 4220: https://www.irs.gov/pub/irs-pdf/p4220.pdf

\section{References}

Internal Revenue Service. (2018). Publication 4220: Applying for 501(c)(3) Tax-Exempt Status. Retrieved from https://www.irs.gov/pub/irs-pdf/p4220.pdf

National Council of Nonprofits. (2015). Tips when fundraising in multiple states. Retrieved from https:// www.councilofnonprofits.org/thought-leadership/ tips-when-fundraising-multiple-states 
National Council of Nonprofits. (2019). Benefits of filing the 501(h) election. Retrieved from https://www.councilofnonprofits.org/benefits-of-filing-the-501h-election 